\title{
Specificity and occupational risks of helping workers
}

\author{
I. V. Astramskaya \\ Kyiv National Taras Shevchenko University \\ Corresponding author. E-mail: arin9474@ukr.net \\ Paper received 11.03.18; Accepted for publication 20.03.18.
}

\section{http://doi.org/10.31174/SEND-PP2018-162VI66-15}

Abstract. The theoretical research is devoted to the clarification of the state of the development of the problem of the specificity of helping professions in modern scientific literature. The features of the professions of assistance are determined. Scientifically theoretically grounded stressogenicity, emotional saturation of subject-object interaction in helping professions. The necessity of further solving the problem of professional deformation of the workers of helping professionals from the point of view of development of preventive, corrective and restoration work for its elimination is proved.

Keywords: help, auxiliary professions, emotional burnout, professional deformation, personality traits, empathy, stress resistance, emotional load.

Introduction. In recent years,social practice and scientific psychological research increasingly encountered the concept of "helping the profession" [2], [8].

The reasons for the increased interest in the representatives of helping professions, on the one hand, are related to socio-economic transformations, the ever-increasing level of stressful living conditions, which increases the importance of helping professions [11] and, on the other hand, with the increasing requirements for professionals of different profiles, and especially representatives of the professions of sociological type [9], [4]

Researchers note that the work of representatives of professions such as "man-man" requires large psychological and physiological costs that lead to emotional strain, and subsequently to emotional, physical and mental exhaustion, which is the basis for the appearance of psychosomatic disorders and diseases.

To particularly strong occupational stress among sociooccupational professions are the representatives of helping specialties, which include medical workers, psychologists, social workers, teachers [2], [11], ie those professionals whose activity, willingness to provide assistance, depends on the effectiveness of work in general .

Disappointments in the profession, the deterioration of the quality of work, and the reduction of overall mental health, which accompany long-term stress, affect not only the quality of professional assistance provided by professionals, but also social health in general. The special vulnerability of the representatives of auxiliary professions is due to the specificity of professional support activities, which is considered by modern psychological science in various aspects.

Purpose -determining the state of development of the problem of the specificity of helping professionals and related professional risks.

Materials and methods. Theoretical analysis of scientific sources and generalization of scientific literature on the research problem; the method of comparative analysis and synthesis of data synthesis, system, structural and functional methods used to determine the directions and conceptual foundations for the study of sociopsychological foundations of helping professions.
Browse articles by topic. Results and discussion. Help as a professional activity. According to the classification of E.A. Klimova [7], professions such as "manman", connected with the constant work with people, include professions in the field of medical care, education and upbringing, domestic services, legal protection. It is this group of specialties that distinguishes a range of professions aimed at helping a person, groups of people in difficult problem situations that require support. The spectrum of "helping" includes professions related to medicine, psychology, teaching and social work [2], [11]. It combines this spectrum of socio-occupational professions to help characterize activities that are based on helping relationships.

By K. Rogers\&apos;s definition, "helping reletions"are "relationships in which at least one of the parties intends to promote the other side in personal growth, development, better life, maturity, and ability to deal with others" [16].

E.P. Korablina, L.A. Kolchanova emphasizes [8] that helping to become professional should be purposeful, that is, the improvement of the functioning of the person to whom the assistance is given should serve as the main goal rather than the accidental result. In addition, special knowledge, skills and abilities should be applied to those who are consciously aware of the direct nature of the interaction. Professional helping activity focuses on the body or the psyche and is to maintain and maintain health, psychological and mental development.

The professions of the assisting type refer to the professions of "higher type", the originality of which is that the result of activity depends on the very subject of activity, determined by the features and properties of his personality, which is the "tool" of work. T.V. Formanyuk notes [17] the inherent creative activity of such activity, accompanied by a sense of constant novelty, and hence the need for constant adaptation, work on oneself, selfdevelopment.

Assistive activities are carried out in the course of communication, requires developed communication skills, orientation to another as an equal participant in the interaction, the ability to accept criticism, objectively assess their role in the work that characterizes the professional 
assisting activities as activities with high moral responsibility for the nature of interaction and its results [12]. O. A. Yedyshova emphasizes that "responsibility to a greater extent relies on the personality that provides assistance, it consciously accepts it" [6].

Emotional stress experienced by professionals assisting the professions from constant interaction with people and immense responsibility for it, is increasing according to V.V.Miłakowo because of the uncertainty of the result of the work, which is impossible to assess objectively, "moreover, it can be estimated directly opposite the various" customers "at various times" [12], while, according to G.S. Abramova [1], the most important condition in which the professions of this type are preserved, is their social significance.

Psychological peculiarities of specialists assisting professions. Assisting activities are not so much in using certain methodical techniques as in personal engagement [9], [10]. The person providing the help is the main factor of influence, and acts as "I-as-instrument" [14]. The researchers emphasize [9], [16] that the actions of professional helping reach the goal only if it creates an atmosphere of openness and dovirchosti safe space in which the person receiving care can solve their problems personally grow and develop

To this end, the specialist should have the following qualities: communicability, socialism, willingness to work and assistance, democracy, tolerance, flexibility, sincerity, kindness, sensitivity, charity and humanism [8]. He must develop verbal abilities, formed the ability to listen and hear a person, to understand his inner world. However, the most important features of the personality of the assisting specialist, which are healing and supportive for the person receiving the help, are the adoption of personal orientations and individual characteristics of the other, inferiority and empathy [10].

"Accepting", "unconditional" communication, the ability to perceive a person as it is, without conviction, is based, as stresses V.A. Vinocour [3], on the principle of human self-worth, allows a person who receives assistance to not perceive interference in his life as a contemptuous intervention, but to jointly look for opportunities for changing the situation. It is in this case that the assistance provided by a specialist allows the person who receives it to demonstrate their abilities, to discover and realize their potential, to exercise their rights to free development, to provide a sense of independence in solving life\&apos;s tasks. The "adoptive" attitude suggests, according to E.P. Korablina [10] humanistic orientation: high level of motivation to work, predominance of cognitive, altruistic motives, positive, optimistic mood, belief in the possibility of changes in the person receiving assistance.

Analyzing these most important features of the personality of a specialist, E.P. The shipwoman emphasizes [10] their female, maternal grounds. Help, like caring for another person, compassion and empathy, are ways of being, which are more intrinsic to a woman. They turn the person inside, orient themselves into their own inner world.

Assistance activities related to the humanitarian type of work are as personal as possible. Activity, the subject of which is the world of human relations, can not be separated from an individual. The personality of the assisting specialist is a means of action, therefore, as noted by A.K. Osnitsky [13], mastering the means of their activities for a specialist means means to master oneself. That is why the most important characteristics of helping specialists in the classics of humanistic psychology (K. Rogers, A. Maslow, etc.) were congruent with respect to themselves, the desire for self-development and self-actualization.

An assistant specialist needs to develop his own personal qualities, not only for their effective use in their work, K. Rogers noted [15]: "If I have to contribute to the personal growth of others in relationships with me, then I must grow myself; and although it is often painful, but very enriching. "

Goals and results in the professions that help [18] are distinguished by three main features. First, in most cases the result of labor in these professions is not defined, but in the form of a general idea. Often, a predictable product is described only through the necessary consequences: something must be done so that, for example, a person feels better. Secondly, in the professions that help, the product is, in one way or another, a "personal contribution", that is, its existence is inseparable entirely from the individual, from the author. Personality as it is present in the realized case, in this case, the activity acts as an author. And, finally, the product of labor in the professions that help, is practically impossible to evaluate objectively, moreover, it can be estimated directly opposite to different "consumers" at different times. This, in turn, involves the maximum amount of internal control over the professional activity and the "correct" representation of the professional about her subject, means, etc.

The lack of clear criteria in the activity, the inability to fully predict the subject-subjective interaction requires doctors, psychologists, teachers and social workers to tolerate uncertainty. Assisting specialist, faced with a problem situation, often operates in the absence of information, he is compelled to take responsibility for the chosen ways of doing business, which requires specialists of this profile of stress, discipline, courage and responsibility [12]. Of great importance in the professional activities of assisting professionals is self-criticism, the ability to recognize their mistakes, not afraid of failures that are inevitable in dealing with the high cognitive complexity of interpersonal communication.

The professional activity of a helping expert is characterized by emotional saturation, energy expenditure on the regulation of their own emotional states and an empathic hearing. S.V. Danilov notices [5] that helping a specialist is a kind of "emotional donor", so he needs to be able to manage the emotional tension of communication.

Conclusions. The specifics of professional assisting activities include certain personal characteristics of the specialists assisting the professions which are considered, on the one hand, as those that determine the choice of profession, and on the other hand, as those formed as a result of professional activity. The presence of these features, abilities and qualities ensures the effectiveness of the professional activities of representatives of assisting professions.

Thus, the professional activity of assisting specialists, the means of which is the person itself, as any other, requires the strengthening and development of certain personal qualities. However, the excessive development of 
these qualities is accompanied by changes in the structure of the personality of a specialist, which affects it negatively and even destructively. Has influence on the person of the assisting specialist and stressfulness of work, high emotional load, felt by doctors, teachers, social workers and psychologists. Specialists in this profile are the most prone to professional deformation. To date, psychology describes many factors that contribute to the emergence of professional deformation of the person helping professionals. The identified problem requires further solution in terms of the development of preventive, corrective and restoration work to address it.

\section{ЛІТЕРАТУРА}

1. Абрамова Г.С. Психология в медицине: Учебное пособие / Г.С. Абрамова, Ю.А. Юдчиц. - М.: ЛПА Кафедра, 1988. $512 \mathrm{c}$.

2. Болучевская В. В. Профессиональное самоопределение будущих специалистов помогающих профессий / В. В. Болучевская - Волгоград: Изд-во ВолГМУ, 2010. - 264 с.

3. Винокур В.А. Методика психологической диагностики профессионального «выгорания» в «помогающих» профессиях [Электронный ресурс] / В.А. Винокур // Медицинская психология в России. N 1. 2010 Режим доступа: medpsy.ru.

4. Вишняков А. И. Гендерные особенности эмоционального сгорания у представителей помогающих профессий / A. И. Вишняков, Т. А. Ульчева // Вестник ОГУ. - Оренбург: ОрГУ, 2005. - №12. - С. 146-150.

5. Данилова С.В. Самоактуализация специалистов помогающих профессий и профессиональные деформации личности // Психолого-социальная работа в современном обществе: проблемы и решения: материалы международной научно-практической конференции, СанктПетербург, 22-23 апреля 2010г. - СПб.: СПбГИПСР, 2010. - $604 \mathrm{c}$.

6. Елдышова О.А. Профессиональное выгорание в помогающих профессиях // Роль служб экстренной психологической помощи по телефону в решении проблемы сиротства в России: I Международная конференция детских телефонов доверия 17-18 ноября 2006 г.: Сборник статей выступлений. - М., 2006. - С. 38-41.

7. Климов Е.А. Индивидуальный стиль деятельности в зависимости от типологических свойств нервной системы / Е.А. Климов. Казань, 1969. 278 с.

8. Кораблина Е. П. Помощь и помогающие / Е. П. Кораблина, Л. А. Колчанова // Вестник Балтийской педагогической академии. - 2002. - № 43. - С. 143-145

9. Кораблина Е. П. Теоретические и прикладные аспекты помогающей деятельности / Е. П. Кораблина // Известия

РГПУ им. А.И. Герцена. Научный журнал. - СПб, 2004. C. 104-113.,

10. Кораблина Е.П. Психологическая помощь как профессиональная деятельность практического психолога / Е.П. Кораблина // Психологические проблемы самореализации личности. Вып. 5 / Под ред. Г.С. Никифорова, Л.А. Коростылевой. СПб., 2001. 161-170.

11. Милакова В. В. Психологические особенности профессионального самоопределения будущих специалистов помогающих профессий социономического типа : автореф. дис. на соискание учен, степени канд. психол. наук : спец. 19.00.13 «Психология развития, акмеология» / В. В. Милакова. - Астрахань, 2007. - 20 с.

12. Милакова В.В. Психологические аспекты профессиональной подготовки специалистов помогающих профессий / В.В. Милакова // Образовательная и молодежная политика в России: проблемы и перспективы: сб. докл. междунар. науч.- практ. конф. ИЗОП. - Новосибирск, 2006. -177 c. - C. $81-83$

13. Осницкий А.К. Умения саморегуляции в профессиональном самоопределении учащихся / А.К. Осницкий // Вопросы психологии. - 1992. - № 1, 2

14. Рейковский Я. Просоциальная деятельность и понятие собственного «Я» / Я. Рейковский // Вестн. Моск. ун-та. Cep.14. - 1981. - №1. - С. 14-22

15. Роджерс К. Взгляд на психотерапию. Становление человека / К. Роджерс. - М.: Прогресс, 1994.- 480 с.

16. Роджерс К. Несколько важных открытий / К. Роджерс // Вестн. МГУ. Серия 14. Психология. 1990. N2. С.58 - 65.

17. Форманюк Т.В. Синдром «эмоционального сгорания» как показатель профессиональной дезадаптаци учителя // Вопросы психологии - 1994. - №6. - С.57-64.

18. Эннс Е.А. (Елена Александровна). Психологическая характеристика помогающих профессий [Текст]//Современная психология: материалы междунар. заоч. науч. конф.- Пермь: Меркурий, 2012. - iv, 94 c.

\section{REFERENCES}

1. Abramova G.S. Psychology in medicine: Textbook / G.S. Abramova, Yu.A. Yudchits - Moscow: LPA Department, 1988. 512 p.

2. Boluchevskaya V.V. Professional Self-Determination of Future Professionals Assisting Professions / VV Boluchevskaya - Volgograd: VolgMGU Publishing House, 2010. $264 \mathrm{p}$.

3. Vinokur V.A. Method of psychological diagnostics of professional "burnout" in "helping" professions [Electronic resource] / V.A. Winokur // Medical psychology in Russia. N 1. 2010 Access mode: medpsy.ru.

4. Vishnyakov A.I. Gender Features of Emotional Combustion in Representatives of Assisting Occupations / A.I. Vishnyakov, T. A. Ulcheva // Bulletin of the OGU. - Orenburg: OrgSU, 2005. - №12. - P. 146-150.

5. Danilova S.V. Self-actualization of specialists assisting professions and professional deformations of the person // Psychological and social work in the modern society: problems and solutions: materials of the international scientific and practical conference, St. Petersburg, 22-23 April, 2010. - SPb : SPbGIPPR, 2010. - 604 p.

6. Eldyshova O.A. Professional Burnout in Assisting Professions // The Role of Emergency Psychological Assistance by Tele-

phone in Solving the Problem of Orphanhood in Russia: I International Conference of Children\&apos;s Telephones of Trust November 17-18, 2006: Collection of articles of speeches. - M., 2006. - P. 38-41.

7. Klimov E.A. Individual style of activity depending on typological properties of the nervous system / E.A. Klimov Kazan, $1969.278 \mathrm{p}$.

8. Korablina E.P. Help and helpers / E.P. Korablyna, L. A. Kolchanova // The Bulletin of the Baltic Pedagogical Academy. 2002. - No. 43. - pp. 143-145

9. Korablina, E.P, Theoretical and Applied Aspects of Assisting Activities / E.P. Korablina // Izvestiya RGPU im. AI Herzen Scientific Journal. - SPb, 2004. - P. 104-113.

10. Korablina E.P. Psychological help as a professional activity of a practical psychologist / E.P. Korablina // Psychological problems of self-realization of personality. Yield 5 / Ed. G.S. Nikiforova L.A. Corostatic St. Petersburg, 2001. 161-170.

11. Milakova V.V. Psychological features of professional selfdetermination of future specialists assisting professions of the socio-type type: author\&apos;s abstract. dis for obtaining academic degree, candidate degree. psychologist Sciences: special 19.00.13 "Psychology of development, acmeology" / V.V. Milakova. - Astrakhan, 2007. - 20 p. 
12. Milakova V.V. Psychological Aspects of Professional Training of Professionals Assisting Professions / V.V. Milakova // Educational and youth policy in Russia: problems and perspectives: Sat. doc. international scientific practical conf. IZOP - Novosibirsk, 2006. - 177 pp. - P. 81-83

13. Osnitsky A.K. Self-regulation skills in professional selfdetermination of students / A.K. Osnitsky // Questions of psychology. - 1992. - № 1, 2

14. Raykovsky Ya. Prosocial activity and the concept of own "I" / Ya. Reykovsky // Vestn. Moscow un-that - Aug.14. - 1981 №1. - P. 14-22
15. Rogers K. A Look at Psychotherapy. The Formation of Man / K. Rogers. - Moscow: Progress, 1994. - 480 p.

16. Rogers K. Several important discoveries / C. Rogers // Vestn. MSU. Series 14. Psychology. 1990. N2. Pp. 58 - 65

17. Formanyuk T.V. The syndrome of "emotional burning" as an indicator of professional teacher\&apos;s disadaptation // Questions of psychology - 1994. - №6. - p. 57-64.

18. Ens E.A. (Elena Aleksandrovna). Psychological characteristic of helping professions [Text] // Modern psychology: materials internationally. behind scientific Conf. - Perm: Mercury, 2012. - iv, 94 p.

\section{Специфіка та професійні ризики працівників допомогаючих професій}

\section{I. В. Астремська}

Анотація. Теоретичне дослідження присвячено з'ясуванню стану розробки проблеми специфіки допомогающих професій в сучасній науковій літературі. Визначено особливості професій допомоги. Науково теоретично обгрунтовано стресогенність, емоційну насиченість суб'єкт-об'єктної взаємодії в допомогаючих професіях. Доведена необхідність подальшого вирішення проблема професійної деформації працівників допомогаючих професій з точки зору розробки засобів профілактичної, корекційно-відновлювальної роботи щодо ії усунення.

Ключові слова: допомога, допомогаючі професії, емочійне вигорання, професійна деформація, особистісні особливості, емпатія, стресостійкість, емоиійне навантаження.

\section{Специфика и профессиональные риски работников помогающих профессий}

\section{И. В. Астремська}

Аннотация. Теоретическое исследование посвящено выяснению состояния разработки проблемы специфики допомогающих профессий в современной научной литературе. Определены особенности профессий помощи. Научно теоретически обосновано понятия стрессогенность, эмоциональная насыщенность субъект-объектного взаимодействия в помогающих профессиях. Доказана необходимость дальнейшего решения проблемы профессиональной деформации работников помогающих профессий с точки зрения разработки средств профилактической, коррекционно-восстановительной работы по ее устранению.

Ключевые слова: помощь, помогающие профессии, эмоциональное выгорание, профессиональная деформащия, личностные особенности, эмпатия, стрессоустойчивость, эмоциональная нагрузка. 